V.V. Goman, V.A. Prakht, V.M. Kazakbaev, V.A. Dmitrievskii, E.A. Valeev, A.S. Paramonov

\title{
ANALYSIS OF THE PAYBACK PERIOD OF A MODERNIZED PUMP UNIT WITH INDUCTION ELECTRIC MOTORS OF ADVANCED ENERGY EFFICIENCY CLASSES
}

\begin{abstract}
Aim. The comparative analysis of energy consumption, electricity costs during lifetime cycle and payback period of a pump unit with $90 \mathrm{~kW}$ 2-pole induction motors, belonging to various energy efficiency classes, feeding directly from power grid. Methods. The examined operating modes aligned with a typical operating cycle of a pump unit with approximately constant flow rate of 75 $110 \%$ of the rated flow. The calculations were based on the pump and induction motors nameplate data, which, in their turn, were based on the manufacturers' experimental data. Results. The calculations of energy consumption, electricity costs and payback periods of a pump unit with $90 \mathrm{~kW}$ 2-pole induction motors, feeding directly from power grid have been performed in the article. The application of induction motors belonging to IE2, IE3 and IE4 energy efficiency classes has been discussed. Practical value. It has been demonstrated, than in case of replacement of an induction motor of energy efficiency class IE2 due to planned retrofit, payback period for an IE4 induction motor is 2.18 years, energy savings within a calculated 20-year operating period are $268 \mathrm{MW} \cdot h$, which makes $€ 41110$ in money terms. Under the same conditions, the replacement of an induction motor of energy efficiency class IE2 with an induction motor of energy efficiency class IE3 will allow to save $88 \mathrm{MW} \cdot \mathrm{h}$ within a calculated operating period, which, expressed in monetary terms, is $€ 13500$ and the payback period is 5.11 years. Thus, the article proves that despite a higher initial price, the choice of an induction motor of energy efficiency class IE4 tends to be more economically advantageous. References 27 , tables 4, figures 1 .

Key words: centrifugal pump, energy efficiency, energy efficiency class, induction motor, throttling control, energy saving, lifetime cycle, payback period.
\end{abstract}

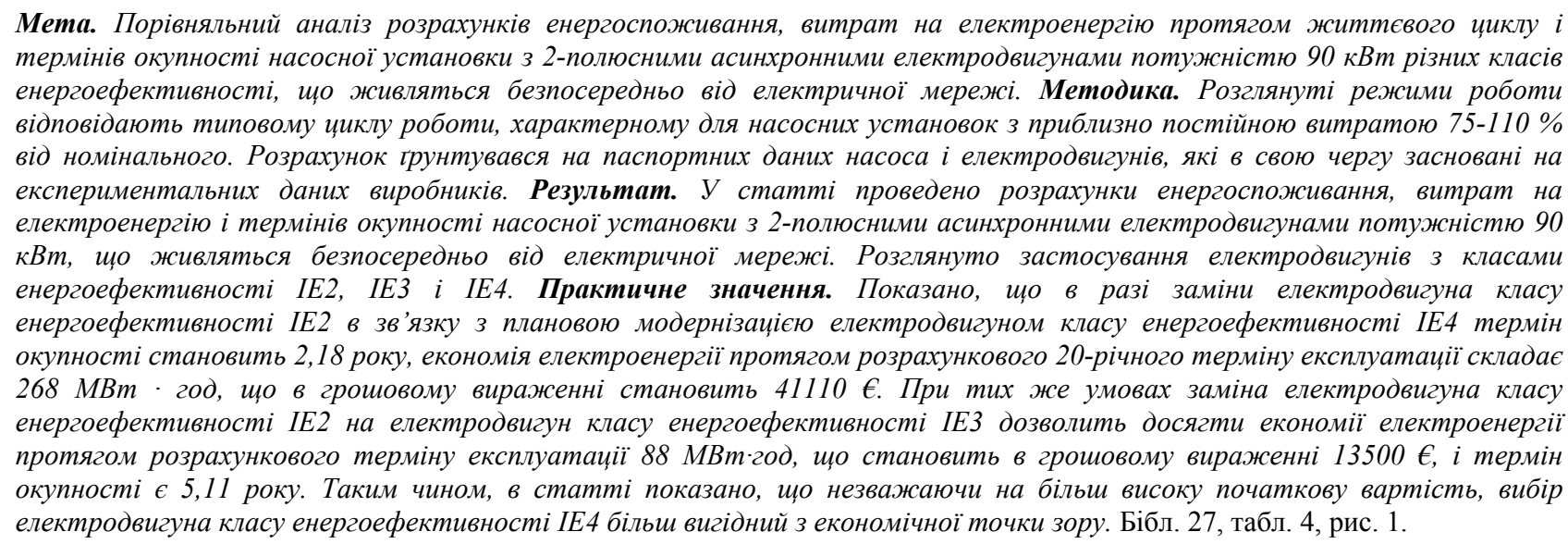
Ключові слова: відцентровий насос, енергоефективність, клас енергоефективності, асинхронний електродвигун, дросельне регулювання, енергозбереження, життєвий цикл, термін окупності.

Цель. Сравнительный анализ расчетов энергопотребления, затрат на электроэнергию в течение жизненного цикла и сроков окупаемости насосной установки с 2-полюсными асинхронными электродвигателями мощностью 90 кВт различных классов энергоэффективности, питающимися напрямую от электрической сети. Методика Рассматриваемые режимь работы соответствовали типовому циклу работы, характерному для насосных установок с приблизительно постоянным расходом 75-110\% от номинального. Расчет основывался на паспортных данных насоса и электродвигателей, которые в свою очередь основаны на экспериментальных данных производителей. Результат В статье произведен расчетьл энергопотребления, затрат на электроэнергию и сроков окупаемости насосной установки с 2-полюсными асинхронныли электродвигателями мощностью 90 кВт, питающимися напрямую от электрической сети. Рассмотрено применение электродвигателей с классами энергоэффективности IE2, IE3 и IE4. Практическое значение. Показано, что в случае замены электродвигателя класса энергоэффективности IE2 в связи с плановой модернизачией электродвигателем класса энергоэффективности IE4 срок окупаемости для электродвигателя класса энергоэффективности IE4 составляет 2,18 года, экономия электроэнергии в течение расчетного 20-летнего срока эксплуатации составляет $268 \mathrm{MBm} \cdot 4$, что в денежном выражении составляет $41110 €$. При тех же условиях замена электродвигателя класса энергоэффективности IE2 на электродвигатель класса энергоэффективности IE3 позволит достичь экономии электроэнергии в течение расчетного срока эксплуатаџии $88 \mathrm{MBm} ч$, что составляет в денежном выражении $13500 €$, и срока окупаемости 5,11 года. Таким образом, в статье показано, что, несмотря на более высокую начальную стоимость, выбор электродвигателя класса энергоэффективности IE4 более выгоден с экономической точки зрения. Библ. 27, табл. 4, рис. 1.

Ключевые слова: центробежный насос, энергоэффективность, класс энергоэффективности, асинхронный электродвигатель, дроссельное регулирование, энергосбережение, жизненный цикл, срок окупаемости.

Introduction. In the world and, in particular, in the European Union, work has long and consistently been carried out to increase the energy efficiency of household appliances, industrial equipment and technological processes. An important part of it is the establishment of energy efficiency classes for electric motors, both powered directly from the electrical network [1], and operating as part of a variable frequency drive (VFD) [2].

(C) V.V. Goman, V.A. Prakht, V.M. Kazakbaev, V.A. Dmitrievskii, E.A. Valeev, A.S. Paramonov 
This is due to the fact that according to the research [3], electric motors consume $46 \%$ of the electricity generated in the world, and the share of electricity consumption by electric motors in industry is about $70 \%$.

In accordance with the EU regulation [4] of 2009, with the addition of 2014, from January 1, 2017 all electric motors with power from 0.75 to $375 \mathrm{~kW}$, with the exception of those specified in the Standard, must have an energy efficiency class of at least IE3 or IE2, if they are used as part of a VFD. In 2019, the requirements for the energy efficiency of electric motors were updated in the new EU regulation [5], according to which the scope of application of the requirements was expanded and the timing of the introduction of more stringent requirements was determined. So, in [5] it is indicated that from July 1, 2021 2-, 4-, 6-, 8-pole electric motors with power from 0.75 to $1000 \mathrm{~kW}$, with the exception of those specified in the Standard, must have an energy efficiency class of at least IE3. From July 1, 2023 2, 4, 6-pole electric motors from 75 to $200 \mathrm{~kW}$ inclusive must have an energy efficiency class of at least IE4 [5]. In the USA, Switzerland, Turkey, Canada, Mexico, South Korea, Singapore, Japan, Saudi Arabia, Brazil, Taiwan and a number of other countries, the use of electric motors with an energy efficiency class of at least IE3 is mandatory [6].

The relevance of the work. According to a European Commission report [3], pumping systems account for almost $22 \%$ of the energy consumed by electric motors worldwide. Therefore, studying the possibilities of increasing the energy efficiency of pumping units is an urgent task.

Centrifugal pumps often do not require a wide control range, as well as high starting torque and speed. Therefore, induction electric motors (IMs), operating directly from the electrical network, are widely used in the drives of the mechanisms mentioned above. In this case, the regulation of the performance of the pumps is carried out using valves (throttle control), by means of a controlled change in the characteristics of the hydraulic network. It is known that due to the high costs of frequency converters, not only pumps are characterized by the use of electric motors powered directly from the electrical network. For example, according to the European Commission [1], the share of VFD was about $30 \%$ for Germany, and about $20 \%$ for Switzerland, according to the study described in [7].

Increasing the energy efficiency of a pumping unit is possible due to changes in the hydraulic network on which the unit operates, the use of VFDs, optimization and distribution of loads (in the case of parallel pumping units), as well as due to the proper selection of unit elements, in particular the use of higher energy efficiency class electric motors [8]. A large number of articles [9-12] are devoted to the issues of reducing the energy consumption of pumping units by using electric motors of different operating principles of higher energy efficiency classes. However, in all of the above-mentioned articles [9-12], a method of regulating pump performance using a VFD is considered. This article discusses the use of electric motors with a higher energy efficiency class, as the most relevant way to improve the energy efficiency of pumps with throttle control.
Note that the classification of electric motors for energy efficiency in the regulatory documents $[1,5]$ is based only on the efficiency in the nominal operating mode, i.e. at rated shaft power, and does not take into account the efficiency of electric motors at a load different from the rated load, which is more or less characteristic of electric motors as part of pumping units. So, for circulating pumps with power up to $2.5 \mathrm{~kW}$ operating mainly with variable flow rate according to [13-15], the relative operating time in the nominal mode does not exceed $6 \%$.

For water pumps, according to [16], standard operating modes with flaw rate of $75 \%, 100 \%$ and $110 \%$ of the nominal flow rate are adopted, and the requirements for energy efficiency in these modes are presented. In [14, 15], a typical operating cycle for these modes is given, typical for pumping systems with an approximately constant flow rate. This profile assumes operation $25 \%$ of the time at $75 \%$ flow, $50 \%$ of the time at nominal flow rate and $25 \%$ of the time at $110 \%$.

Literature review. In [17], a pump unit with nominal power of $2.2 \mathrm{~kW}$ operating at a variable flow rate was analyzed. Line-start permanent magnet synchronous motors and IMs with energy efficiency classes IE3 and IE4 were considered. Annual electricity consumption, annual electricity costs, share of life cycle costs determined by the cost of electricity and annual energy savings in kind and in monetary terms when choosing an electric motor were calculated. However, the calculation of the payback period was not made, since the main goal of the article was to show that the choice of an electric motor only according to the energy efficiency class, which is assigned according to the efficiency at the rated load, does not lead to the minimum energy consumption when operating a pumping unit with a variable flow rate according to the typical operating cycle given in [13].

In the article [18], the analysis of the same indicators was carried out for a pumping unit operating at an approximately constant flow rate, with power of $11 \mathrm{~kW}$ with two IMs of energy efficiency classes IE1 and IE2, and the payback periods of technical solutions for replacing an electric motor of class IE1 with an electric motor of class IE2 were calculated. However, it should be noted that replacing the IE1 energy efficiency class with IE2 electric motors is relevant only in some countries. For example, in the countries of the Eurasian Economic Union (Russia, Kazakhstan, Belarus, Kyrgyzstan, Armenia), the legislation of which in the field of energy efficiency [19] does not prohibit the use of electric motors of the IE1 class until September 1, 2021.

Thus, as the review of literature sources shows, a comparative analysis of energy consumption and economic indicators of operation of electric motors of energy efficiency classes IE2, IE3, IE4 in pumping units of medium and high power with throttle regulation and approximately constant flow rate has not been previously carried out.

The goal of the work is a comparative analysis of energy consumption and payback periods of a pumping unit using 2-pole IMs of energy efficiency classes IE2 [20], IE3 [21] and IE4 [22] of power of $90 \mathrm{~kW}$ from one manufacturer, powered directly from the mains, for a 
typical cycle of operation, typical for an approximately constant flow rate according to $[14,15]$.

Initial data and calculation methods. For the calculation, the data of the pump Grundfos NB 65315/308 AF2ABAQE - 97836805 [23] with rated power $P_{\text {RATE }}=90 \mathrm{~kW}$ and rated speed $n_{\text {RATE }}=2980 \mathrm{rpm}$ are used. Pump data are given in Table 1 , where $Q_{B E P}$ is the flow rate at the best efficient point (BEP) and $H_{B E P}$ is the pump pressure at the BEP.

Table 1

Pump passport data
\begin{tabular}{|c|c|}
\hline Parameter & Value \\
\hline Type & NB $65-315 / 308$ \\
\hline$P_{\text {RATE }}, \mathrm{W}$ & 90000 \\
\hline$n, \mathrm{rpm}$ & 2980 \\
\hline$Q_{B E P}, \mathrm{~m}^{3} / \mathrm{h}$ & 182 \\
\hline$H_{B E P}, \mathrm{~m}$ & 120.6 \\
\hline Efficiency, \% & 73.8 \\
\hline
\end{tabular}

The graphs of the main characteristics of the pump (dependence of pressure, power consumption and efficiency on flow) are shown in Fig. 1.
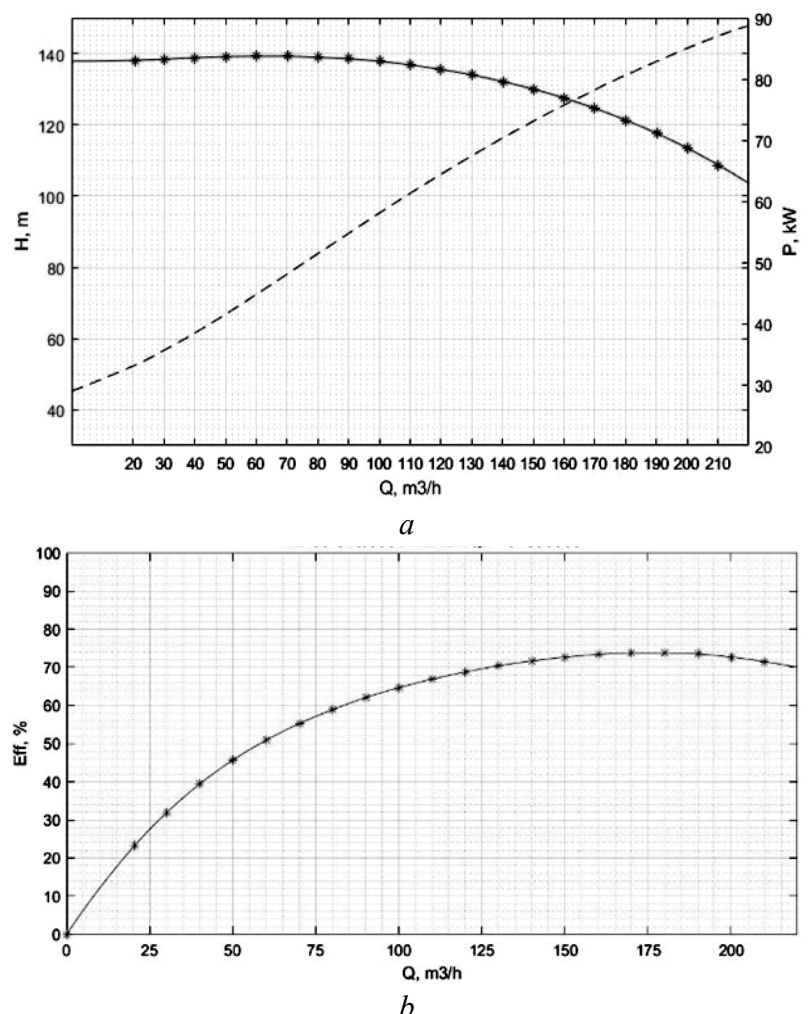

Fig. 1. Interpolated pump characteristics and reference points from catalog data:

a) $Q-H$ characteristic and power consumption versus flow rate; $b$ ) dependence of pump efficiency on flow

The active power of the $m$-th IM in the $i$-th operating mode consumed from the electrical network was calculated according to (1) taking into account the interpolated values of the efficiency of electric motors $\eta_{\text {M.i.m }}$ and the mechanical power $P_{\text {mech.i.m }}$ for modes corresponding to a typical cycle of operation, similar to the approach used in work [17]

$$
P_{1 . i . m}=P_{\text {mech.i.m }} / \eta_{\text {M.i.m. }} \text {. }
$$

The annual energy consumption for each IM in the considered typical operating cycle of the pumping unit, taking into account year-round and round-the-clock operation, was determined as

$$
E_{\text {d.m. }}=365 \cdot t_{\Sigma} \cdot \sum_{i=1}^{3}\left(P_{1 . i . m} \cdot \frac{t_{i}}{t_{\Sigma}}\right) .
$$

where $t_{\Sigma}$ is the total operating time taken equal to $24 \mathrm{~h}$ and $t_{i}$ is the operating time in each mode.

Electricity cost $(€)$ at tariff $G T=€ 0.188 / \mathrm{kWh}$ for industrial consumers in Germany in the second half of 2019 [24] was determined by the formula

$$
C_{y, m}=E_{y, m} \cdot G T \text {. }
$$

The annual cost savings in electricity were calculated as

$$
S_{y .31}=C_{y .3}-C_{y .1} ; S_{y .32}=C_{y .3}-C_{y .2} ; S_{y .21}=C_{y .2}-C_{y .1} \text {. }
$$

Taking into account that the life cycle of pumping units according to the data $[25,26]$ is about $15-20$ years, for the calculations the service life was assumed $n=20$ years. The electricity costs were calculated over the life cycle of the pumping unit, since the total cost of the life cycle of a pumping unit is mainly the cost of consumed electricity (at least more than 50-60\%) [25, 26]. The net present value $(N P V)$ of the life cycle, determined by the cost of electricity consumed, was calculated as

$$
C_{\text {LCCen.m }}=C_{y . m} /(1+(y-p))^{n},
$$

where $y$ is the interest rate (taken equal to 0.04 ) and $p$ is the expected annual inflation (taken equal to 0.02 ) [25, 26].

The difference in electricity costs during the life cycle of the $m$-th IM relative to the existing IM was determined as

$$
\Delta C_{L C C e n .3 m}=C_{L C C e n .3}-C_{L C C e n . m} .
$$

In the case of replacing the existing IM of the IE2 energy efficiency class with an IE4 or IE3 IM, the payback period $T_{m}$ of the $m$-th IM was determined as

$$
T_{m}=C_{i i c . m} / S_{y .3 m} \text {. }
$$

where $C_{i i c . m}$ is the initial cost of the considered electric motors, which are given in Table 4 according to [27].

Results of calculations and their discussion. Table 2 shows the results of calculating the pump operating modes.

Table 2

Results of calculating the pump operating modes

\begin{tabular}{|l|c|c|c|}
\hline $\begin{array}{c}\text { Number of } \\
\text { modes }(i)\end{array}$ & 1 & 2 & 3 \\
\hline$Q_{i}, \%$ & 75 & 100 & 110 \\
\hline$Q_{i}, \mathrm{~m}^{3} / \mathrm{h}$ & 136.5 & 182.0 & 200.2 \\
\hline$H_{\text {pump. } i}, \mathrm{~m}$ & 132.6 & 120.6 & 113.9 \\
\hline$\eta_{\text {pump } \cdot \text {, } \%}, \mathrm{~W}$ & 71.3 & 73.8 & 72.7 \\
\hline$P_{\text {mech. } i}, \mathrm{~W}$ & 69176 & 81045 & 85471 \\
\hline$P_{\text {mech } \cdot}, \%$ & 76.86 & 90.05 & 94.97 \\
\hline
\end{tabular}

Table 3 shows the efficiency values of electric motors according to the catalog for loads of $50 \%, 75 \%$ and $100 \%$, as well as for each operating mode of the pump in accordance with the considered typical operating cycle.

The calculation results using (1)-(7) are shown in Table 4. If an IE2 electric motor in an existing pumping unit is replaced by an IE4 electric motor, the energy savings over the design life are $268 \mathrm{MWh}$, which is $€$ 41,100 in monetary terms, and the payback period is 2.18 years. In case of replacement with an electric motor of the energy efficiency class IE3, the energy savings during the 
Table 3

Initial and interpolated efficiency values of electric motors

\begin{tabular}{|c|c|c|c|c|}
\hline \multirow{2}{*}{$m$} & \multirow{2}{*}{$\begin{array}{c}\text { Electric motor type, } \\
\text { IE class }\end{array}$} & $\begin{array}{c}\text { Efficiency according to catalog } \\
\text { data, \% at load }\end{array}$ \\
\cline { 3 - 5 } & & $50 \%$ & $75 \%$ & $100 \%$ \\
\hline 1 & IM WEG W22, IE4 & 95.5 & 96.2 & 96.5 \\
\hline 2 & IM WEG W22, IE3 & 94.3 & 95.2 & 95.2 \\
\hline 3 & IM WEG W22, IE2 & 94.0 & 94.6 & 94.6 \\
\hline \multirow{2}{*}{$m$} & \multirow{2}{*}{$\begin{array}{c}\text { Electric motor type, } \\
\text { IE class }\end{array}$} & $\begin{array}{c}\text { Interpolated values of efficiency } \\
\eta_{\text {M.i.m }} \% \text { in operating modes }\end{array}$ \\
\cline { 3 - 5 } & & 1 & 2 & 3 \\
\hline 1 & IM WEG W22, IE4 & 96.27 & 96.43 & 96.46 \\
\hline 2 & IM WEG W22, IE3 & 95.20 & 95.20 & 95.20 \\
\hline 3 & IM WEG W22, IE2 & 94.60 & 94.60 & 94.60 \\
\hline
\end{tabular}

Table 4

Results of calculating energy consumption and electrical energy savings

\begin{tabular}{|l|c|c|c|}
\hline \multicolumn{1}{|c|}{$m$} & 1 & 2 & 3 \\
\hline $\begin{array}{l}\text { Electric motor type, } \\
\text { IE class }\end{array}$ & $\begin{array}{c}\text { АД WEG } \\
\text { W22, IE4 }\end{array}$ & $\begin{array}{c}\text { АД WEG } \\
\text { W22, IE3 }\end{array}$ & $\begin{array}{c}\text { АД WEG } \\
\text { W22, IE2 }\end{array}$ \\
\hline$E_{y . m}$, MWh & 719.5 & 728.5 & 732.9 \\
\hline$C_{y . m}$, thousand $€$ & 135.27 & 136.96 & 137.78 \\
\hline$S_{y .3 m}, €$ & 2513.4 & 824.8 & 0 \\
\hline$C_{L C C e n . m}$, thousand $€$ & 2211.9 & 2239.5 & 2253.0 \\
\hline $\begin{array}{l}\Delta C_{L C C e n .3 m}, \text { thousand } \\
€\end{array}$ & 41.1 & 13.5 & 0 \\
\hline$C_{i i c . m}, €$ & 5486 & 4220 & 0 \\
\hline$T_{m}$, years & 2.18 & 5.11 & - \\
\hline
\end{tabular}

design life are $88 \mathrm{MWh}$, which is $€ 13,500$ in monetary terms, the payback period is 5.11 years. Thus, for the considered conditions, it is advisable to modernize the pumping unit by replacing the electric motor of the IE2 energy efficiency class. Here, despite the higher cost, the use of an electric motor of the energy efficiency class IE4 will provide a significantly shorter payback period than the use of an electric motor of the class IE3.

Conclusions. In the work, calculations of electricity consumption and cost indicators of energy savings for induction electric motors of IE2, IE3, IE4 classes were made, in the case if they are used in a pumping unit operating with flow rate varying within $75-110 \%$ of the nominal one. A comparison was made of the payback periods and electrical energy costs throughout the life cycle for the case of replacing the electric motor in connection with a planned modernization. The payback period for replacing an IE2 motor with an IE4 motor is 2.18 years. Here, the payback period in case of replacement of an electric motor of the energy efficiency class IE2 with an electric motor of the energy efficiency class IE3 is much longer and amounts to 5.11 years. Thus, the choice of an IE4 motor is more cost-effective when upgrading, even though its cost is $30 \%$ higher than that of an IE3 motor. It should be noted that such a technical solution will be especially relevant in light of the requirements of the document [5], according to which in the European Union the use of IE4 class electric motors for powers above $75 \mathrm{~kW}$ is mandatory from July 1, 2023.

Acknowledgment. The work was partially supported by the Ministry of Science and Higher Education of the Russian Federation (through the basic part of the government mandate, Project No. FEUZ-20200060).
Conflict of interests. The authors declare no conflicts of interest.

\section{REFERENCES}

1. Rotating electrical machines - Part 30-1: Efficiency classes of line operated AC motors (IE code). IEC 60034-30-1/ Ed. 1; IEC: 2014-03. Available at: https://webstore.iec.ch/publication/136 (accessed on 10 June 2020).

2. Rotating electrical machines - Part 30-2: Efficiency classes of variable speed AC motors (IE-code) IEC 60034-30-2/ IEC: 2016-12. Available at: https://webstore.iec.ch/publication/30830 (accessed on 10 June 2020).

3. European Commission. Study on improving the energy efficiency of pumps, 2001. Available at: https://www.jacobalbertsen.dk/komposit/Darmstadtrapport.pdf (accessed on 10 June 2020).

4. European Commission Regulation (EC) No. 640/2009 implementing Directive 2005/32/ EC of the European Parliament and of the Council with Regard to Ecodesign Requirements for Electric Motors, (2009), amended by Commission Regulation (EU) No 4/2014 of January 6, 2014. Document 32014R0004. Available at: https://eurlex.europa.eu/legal-

content/EN/TXT/?uri=CELEX\%3A32014R0004 (accessed on 11 June 2020).

5. Commission Regulation (EU) 2019/1781 of 1 October 2019 laying down ecodesign requirements for electric motors and variable speed drives pursuant to Directive 2009/125/EC of the European Parliament and of the Council, amending Regulation (EC) No 641/2009 with regard to ecodesign requirements for glandless standalone circulators and glandless circulators integrated in products and repealing Commission Regulation (EC) No 640/2009. Available at: https://eur-lex.europa.eu/legalcontent/EN/TXT/PDF/?uri=CELEX:32019R1781\&from=EN (accessed on 10 June 2020).

6. Efficiency regulations for motors: international norms. NORD DRIVESYSTEMS Group, S4700 Part. No. 6069202 / 4019. Available

https://www.nord.com/cms/media/documents/bw/S4700 60692 02 4019 Screen.pdf (accessed on 11 June 2020).

7. Phillips R., Tieben R. Improvement of Electric Motor Systems in Industry (IEMSI). Proceedings of the 10th international conference on energy efficiency in motor driven systems (EEMODS' 2017), Rome, Italy, September 6-8, 2017. pp. 53-67. doi: http://dx.doi.org/10.2760/345473.

8. Arun Shankar V.K., Umashankar S., Paramasivam S., Hanigovszki N. A comprehensive review on energy efficiency enhancement initiatives in centrifugal pumping system. Applied Energy, 2016, vol. 181, pp. 495-513. doi: https://doi.org/10.1016/j.apenergy.2016.08.070.

9. Ahonen T., Orozco S.M., Ahola J., Tolvanen J. Effect of electric motor efficiency and sizing on the energy efficiency in pumping systems. 2016 18th European Conference on Power Electronics and Applications (EPE'16 ECCE Europe), Sep. 2016, Karlsruhe, pp. 1-9. doi: https://doi.org/10.1109/epe.2016.7695671.

10. Van Rhyn P., Pretorius J.H.C. Utilising high and premium efficiency three phase motors with VFDs in a public water supply system. 2015 IEEE 5th International Conference on Power Engineering, Energy and Electrical Drives (POWERENG), May 2015, Riga, pp. 497-502. doi: https://doi.org/10.1109/powereng.2015.7266367.

11. Brinner T.R., McCoy R.H., Kopecky T. Induction versus permanent-magnet motors for electric submersible pump field and laboratory comparisons. IEEE Transactions on Industry Applications, 2014, vol. 50, no. 1, pp. 174-181. doi: https://doi.org/10.1109/tia.2013.2288203. 
12. Kazakbaev V., Prakht V., Dmitrievskii V., Ibrahim M., Oshurbekov S., Sarapulov S. Efficiency analysis of low electric power drives employing induction and synchronous reluctance motors in pump applications. Energies, 2019, vol. 12, no. 6, p. 1144. doi: https://doi.org/10.3390/en12061144.

13. Commission Regulation (EC) No 641/2009 of July 22, 2009 implementing Directive 2005/32/EC of the European Parliament and of the Council with regard to ecodesign requirements for glandless standalone circulators and glandless circulators integrated in products, amended by Commission Regulation (EU) No 622/2012 of July 11, 2012. Document 02009R064120170109. Available at: https://eur-lex.europa.eu/legalcontent/EN/TXT/?uri=CELEX\%3A02009R0641-20170109

(accessed on 11 June 2020).

14. Extended product approach for pumps, Copyright (C) 2014 by Europump. Published by Europump. Available at: http://europump.net/uploads/Extended\%20Product\%20Approac h\%20for $\% 20$ Pumps $\% 20$ -

\%20A\%20Europump\%20guide\%20(27OCT2014).pdf (accessed on 11 June 2020).

15. Stoffel B. Assessing the Energy Efficiency of Pumps and Pump Units. Background and Methodology. Elsevier: Amsterdam, The Netherlands, 2015. doi: https://doi.org/10.1016/b978-0-08-100597-2.00009-4.

16. Commission regulation (EU) No 547/2012 of June 25, 2012 implementing Directive 2009/125/EC of the European Parliament and of the Council with regard to ecodesign requirements for water pumps. Available at: https://eurlex.europa.eu/legal-

content/EN/TXT/?uri=CELEX\%3A32012R0547 (accessed on 11 June 2020).

17. Goman V.V., Oshurbekov S.Kh., Kazakbaev V.M., Prakht V.A., Dmitrievskii V.A. Comparison of energy consumption of various electrical motors operating in a pumping unit. Electrical engineering \& electromechanics, 2020, no. 1, pp. 16-24. doi: https://doi.org/10.20998/2074-272X.2020.1.03.

18. Oshurbekov S.Kh., Kazakbaev V.M., Prakht V.A., Dmitrievskii V.A., Paramonov A.S. Analysis of electricity consumption of induction motors of IE1 and IE2 efficiency classes in a $11 \mathrm{~kW}$ pump installation. Electrical engineering \& electromechanics, 2020, no. 5, pp. 18-24. doi: https://doi.org/10.20998/2074-272X.2020.5.03.

19. Technical regulations of Eurasian Economic Union (TR EAEC 048/2019). About requirements of the energy efficiency of power consuming devices. (Rus). Available at: https://www.garant.ru/products/ipo/prime/doc/73240518/

(accessed on 01 June 2020).

20. W22 High Efficiency IE2 $90 \mathrm{~kW} 2 P$ 280S/M 3Ph 380415/660//460 V 50 Hz IC411 - TEFC - B34T. Product Details. Available at: https://www.weg.net/catalog/weg/CI/en/ElectricMotors/Low-Voltage-IEC-Motors/General-Purpose-ODP-

TEFC/Cast-Iron-TEFC-General-Purpose/W22---Cast-IronTEFC-General-Purpose/W22-IE2/W22-IE2-90-kW-2P-280S-M3Ph-380-415-660-460-V-50-Hz-IC411---TEFC---

B34T/p/12999061 (accessed on 01 June 2020).

21. W22 Premium Efficiency IE3 $90 \mathrm{~kW} 2 P$ 280S/M 3Ph 380415/660//460 V $50 \mathrm{~Hz}$ IC411 - TEFC - B3T. Product Details. Available at: https://www.weg.net/catalog/weg/CI/en/Electric-
Motors/Low-Voltage-IEC-Motors/General-Purpose-ODPTEFC/Cast-Iron-TEFC-General-Purpose/W22---Cast-IronTEFC-General-Purpose/W22-IE3/W22-IE3-90-kW-2P-280S-M3Ph-380-415-660-460-V-50-Hz-IC411---TEFC---

B3T/p/12862411 (accessed on 10 June 2020).

22. W22 Super Premium Efficiency IE4 $90 \mathrm{~kW} 2 \mathrm{P}$ 280S/M 3Ph 400/690//460 V $50 \mathrm{~Hz}$ IC411 - TEFC - B3T. Product Details. Available at: https://www.weg.net/catalog/weg/AZ/en/ElectricMotors/Low-Voltage-IEC-Motors/General-Purpose-ODPTEFC/Cast-Iron-TEFC-General-Purpose/W22---Cast-IronTEFC-General-Purpose/W22-IE4/W22-IE4-90-kW-2P-280S-M3Ph-400-690-460-V-50-Hz-IC411---TEFC---B3T/p/12774372 (accessed on 10 June 2020).

23. NB 65-315/308 AF2ABAQE 97836805. Product Details. Available at: https://product-selection.grundfos.com/productdetail.product-

detail.html custid $=$ GMO\&productnumber $=97836805 \& q$ cid $=10$ 19268753 (accessed on 10 June 2020).

24. Eurostat Data for the Industrial Consumers in Germany. Available at: $\quad$ http://ec.europa.eu/eurostat/statisticsexplained/index.php/Electricity price statistics\#Electricity pric es for industrial consumers (accessed on 11 June 2020).

25. Pump Life Cycle Costs: A Guide to LCC Analysis for Pumping Systems. Executive Summary. Hydraulic Institute (Parsippany, NJ); Europump (Brussels, Belgium); Office of Industrial Technologies Energy Efficiency and Renewable Energy U.S. Department of Energy (Washington, DC). January 2001, pp. 1-19. Available at: https://www.energy.gov/sites/prod/files/2014/05/f16/pumplcc 1 001.pdf.

26. Waghmode L.Y., Sahasrabudhe A.D. A comparative study of life cycle cost analysis of pumps. In Proceedings of the International Design Engineering Technical Conferences and Computers and Information in Engineering Conference (ASME 2010), Montreal, QC, Canada, 15-18 August 2010, vol. 6, pp. 491-500. doi: https://doi.org/10.1115/DETC2010-28034.

27. $A C$ Electric Motor. Available at: https://www.acelectricmotor.co.uk/ (accessed on 11 June 2020).

Received 04.10.2020 Accepted 10.12.2020 Published 25.02.2021

V.V. Goman ${ }^{1}, P h . D .$,

V.A. Prakht ${ }^{2}$, Ph.D.,

V.M. Kazakbaev ${ }^{2}$, Ph.D.,

V.A. Dmitrievskii ${ }^{2}$, Ph.D.

E.A. Valeev ${ }^{1}$, Student,

A.S. Paramonov ${ }^{2}$, Student,

${ }^{1}$ Nizhny Tagil Technological Institute (branch)

of Ural Federal University,

59, Krasnogvardeiskaia Str., Nizhny Tagil,

Sverdlovsk Region, 622013, Russia,

e-mail: v.v.goman@urfu.ru, valieievewot@mail.ru

${ }^{2}$ Ural Federal University,

19, Mira Str., Ekaterinburg, 620002, Russia,

e-mail: va.prakht@urfu.ru,_vadim.kazakbaev@urfu.ru,

vladimir.dmitrievsky@urfu.ru, paramonov.aleksey@inbox.ru

How to cite this article:

Goman V.V., Prakht V.A., Kazakbaev V.M., Dmitrievskii V.A., Valeev E.A., Paramonov A.S. Analysis of the payback period of a modernized pump unit with induction electric motors of advanced energy efficiency classes. Electrical Engineering \& Electromechanics, 2021, no. 1, pp. 15-19. doi: 10.20998/2074-272X.2021.1.03. 